\title{
Technological Monitoring for Hardening and Strengthening of Cement-concrete Compositions
}

\author{
Stackelberg DI*, Vilge BI and Boiko SV \\ Concretec Ltd, Israel \\ *Corresponding author: Stackelberg DI, Concretec Ltd, Israel
}

Submission: 每 December 06, 2018; Published: 眥 December 13, 2018

\section{Introduction}

The properties of Cement-Concrete Compositions (CCC) are in constant change during a hardening process. At initial stages of hardening, the CCC structure is characterized by viscous-plastic properties, while in final hardened structure, an artificial stone, elastic properties dominate. Technological parameters determined by those properties (W/C-ratio, slump, setting times, strength, etc.) mostly are incompatible with each other. This significantly complicates practical implementation of technological monitoring of CCC hardening and strengthening.

In the recent decades, the electrical resistivity method has been successfully employed for solving these problems. The method's use was started with a pioneering work by Schimizu [1] who studied the Portland cement setting by measuring its electrical conductivity. This method is used in modern concrete science for the determination of the W/C-ratio [2] and the water content in concrete [3], research of early stages of cement pastes and mortars' hardening [4-7], determination of the setting time of cement pastes and concretes [8-12], research and evaluation of various structural properties of concretes, including their permeability characteristics [13-17], studies of the strengthening patterns [18-21]. Various measuring sensors were used in these studies, from the Tester type double electrode sensors $[7,11]$ to complex contactless $[4,20]$ and multi-electrode systems [22].

The absolute majority of the cited works refer to laboratory tests. Any successful use of the electrical resistivity method at construction sites [22], precast plants etc. is rather an exception. For the purpose of an efficient study of the CCC properties and in-situ technological monitoring of their various properties, the Israeli company Concrete Ltd. has developed uniform principles of monitoring the hardening and strengthening of cementconcrete compositions, as well as a measurement system for the implementation of such principles [23-25]. The physical base of the method is a continuous evaluation of the porous solution's state in a hardening CCC in accordance with the results of direct measurements of specific electrical resistivity.

The Concrete Ltd. technology features the following distinct possibilities:
A. Versatility of the developed software (the set of registration, processing and interpretation programs) and hardware (measurement equipment, the main elements of which are 8-channel Data Logger and container type measuring sensor), i.e. the possibility of their practical application in either laboratories [26] or at building sites and plants of construction materials and elements [28,29] without readjustment and resetting.

B. Technological monitoring of concrete properties at all stages of construction: starting from a mixture preparation until reaching the concrete final strength; among others the determination of optimal time the for formwork removing [27], transferring of prestressed reinforcement' efforts to concrete, etc.

C. Implementations of laboratory studies and technological monitoring of hardening and strengthening for the entire range of CCC: cement pastes and cement-sand solutions [27], concrete of various types: ordinary OPC concrete [26], shotcrete [27], aerated concrete [28].

The Concrete Ltd. technology has been successfully applied in a number of projects:

a. Construction of the Tel Aviv - Jerusalem railway tunnel-for monitoring the early hardening of shotcrete in arch elements.

b. Plant manufacture of massive concrete elements of a breakwater-for the hardening monitoring.

c. "Považská cementáreň" cement plant (Slovakia)-for monitoring the characteristics' stability of the Portland cement clinker.

d. El Gad (Russia) construction materials plant-for monitoring the rising and pre-autoclave strengthening of aerated concrete.

\section{References}

1. Schimizu Y (1928) The science reports of the Tohoku Imperial University, $1^{\text {st }}$ Series, Shendai, Japan 17(1):423-429. 
2. Mancio M, Moore JR, Brooks Z, Monteiro PJM, Glaser SD (2010) Instantaneous in-situ determination of water-cement ratio of fresh concrete. AC Materials Journal 107(6): 586-592.

3. Brameshuber W, Raupach M, Schröder P, Dauberschmidt C (2003) Non-destructive determination of the water-content in the concrete cover using the multiring-electrode. Part. I: Aspects of concrete technology. International Symposium NDT-CE, Stutgart 2: 41

4. Li Z, Wei X, Li W (2003) Preliminary interpretation of Portland cement hydration process using resistivity measurement. ACI Materials Journal 100(3): 253-257.

5. Wei X, Li Z (2006) Early hydration process of Portland cement paste by electrical measurement. Journal of Materials in Civil Engineering 18(1): 99-105.

6. Xiao L, Li Z (2008) Early-age hydration of fresh concrete monitored by non-contact electrical resistivity measurement. Cement and Concrete Research 38: 312-319.

7. Obla K, Hong R, Sherman S, Bentz DP, Jones SZ (2018) Relating the electrical resistance of fresh concrete to mixture proportions. Adv Civ Eng Mater 7(1): 71-86.

8. Li Z, Xiao L, Wei X (2007) Determination of concrete setting time using electrical resistivity measurement. Journal of Materials in Civil Engineering 19(5): 423-427.

9. Andrade C, Rebolledo N (2011) Setting and hydration evolution by resistivity and ultrasonic velocity. 13 Intern. Congress on the Chemistry of Cement, Abstracts and Proceedings, Madrid 7: 8.

10. Bentz DP, Snyder KA, Ahmed A (2015) Anticipating the setting time of high-volume fly ash concretes using electrical measurements: feasibility studies using pastes. J Mater Civ Eng 27(3): 1-6.

11. Bentz DP (2014) Activation energies of high-volume fly ash ternary blends: hydration and setting. Cement and Concrete Composites 53 214-223.

12. McCarter WJ, Curran PN (1984) The electrical response characteristics of setting cement paste. Magazine of Concrete Research 36(126): 42.

13. Hope BB, Ip AK, Manning, DG (1985) Corrosion and electrical impedance in concrete. Cement and Concrete Research 15(3): 525-534.

14. Lio Y, Presuel Moreno FJ (2014) Normalization of temperature effect on concrete resistivity by method using arrenius law. ACI Materials Journal 3(4): 433-442.

15. Monfore GE (1968) The electrical resistivity of Concrete. Journal of PCA pp. 35-48.
16. Sengul 0, Gjørv OE (2008) Electrical resistivity measurements for quality control during concrete construction. ACI Materials Journal 105(6): 541-547.

17. Xinying Lu (1997) Application of the Nernst-Einstein equation to concrete. Cement and concrete research 27(2): 293-302.

18. Trimbak PV, Jolicoeur C, Khayat KH (2002) Multi-probe conductivity method for monitoring time-depended processes in fresh cementitious and other slurry systems. Canada Patent: CA 2322931.

19. Backe KR, Lile OB, Lomov SK (2001) Characterizing curing cement slurries by electrical conductivity. SPE Drilling \& Completion, pp. 201-207.

20. Wei X, Xiao L (2012) Effect of temperature on the electrical resistivity of Portland cement pastes. Advances in Cement Research 24(2): 69-76.

21. Lubeck A, Gastaldini ALG, Barin DS, Siqueira HC (2012) Compressive strength and electrical properties of concrete with white Portland cement and blast-furnace slag. Cement \& Concrete Composites 34(3): 392 399.

22. McCarter WJ, Chrisp TM, Staars G, Basheer M, Blewett J (2005) Field monitoring of electrical conductivity of cover-zone concrete. Cement and Concrete Composites 27(7-8): 809-817.

23. Shtakelberg DI, Boiko SV, Wilge BI (2007) Method, apparatus and system for forecasting strength of cementitious material. US Patent № $7,181,978$.

24. Shtakelberg DI, Wilge BI, Boiko SV, Milman O (2007) Methods, apparatus and system for monitoring hardening and forecasting strength of cementitious material. US Patent No. 7,225,682.

25. Shtakelberg DI, Wilge BI, Boiko SV (2013) Methods and system for analyzing a chemically-active material. US Patent No. 8,610,444.

26. Shtakelberg DI, Wilge BI, Boiko SV (2018) Apparent activation energy and strengthening during hardening of cement- concrete compositions. Journal of Advanced Concrete Technology 16: 136-144.

27. Shtakelberg DI, Wilge BI, Boiko SV (2014) New principles of monitoring hardening and strengthening of shotcrete. Journal of The Chinese Ceramic Society 42(5): 568-573

28. Stackelberg D, Wilge B, Boiko S, Martauz P, Strigac J (2011) Monitoring the strength properties of cement clinker on the basis of measurements of electrical resistivity. XIII International Congress on the Chemistry of Cement. Madrid 7: 8.

29. Goldman FA, Shtakelberg DI, Gadaev NR, Steinbuk G (2015) Monitoring of hardening of aerated concrete as measured by electrical resistance. Jour/Concrete Technology 3-4: 32-35.
Creative Commons Attribution 4.0 International License

For possible submissions Click Here

\section{Submit Article}

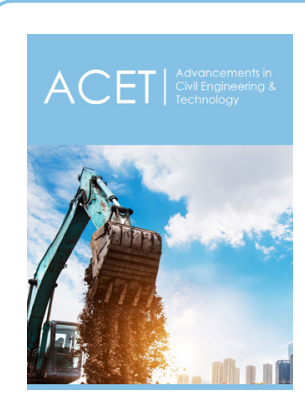

Advancements in Civil Engineering \& Technology

Benefits of Publishing with us

- High-level peer review and editorial services

- Freely accessible online immediately upon publication

- Authors retain the copyright to their work

- Licensing it under a Creative Commons license

- Visibility through different online platforms 